\title{
Religion, Politics, and the Environment in Rural America
}

\author{
MICHELE DILLON AND MEGAN HENLY
}

$\mathrm{I}_{\mathrm{c}}^{\mathrm{n}}$ n February 2006, bestselling author of The PurposeDriven Life, Rick Warren, and other high-profile evangelical leaders issued a public statement declaring their commitment to help fight global warming. In the months since, media commentators and political analysts have linked this environmental turn among evangelicals to broader cultural changes in the evangelical movement. The rise of a new generation of pastors and leaders has, many have argued, expanded the evangelical agenda beyond abortion, gay rights, and creationism.

Not all evangelical leaders, however, have signed on to the environmental cause. Most notably, Charles Dobson of Focus on the Family and Southern Baptist leader Richard Land reject the global warming initiative, seeing it largely as a distraction from more clear-cut biblical imperatives. ${ }^{1}$

Figure 1. Religious Preference by Rural Region
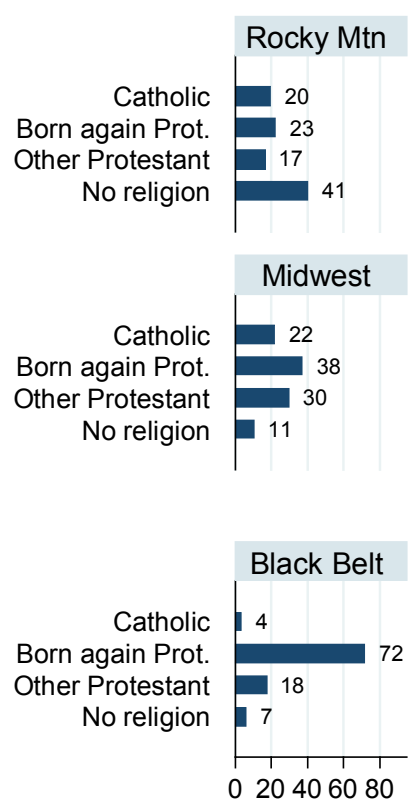
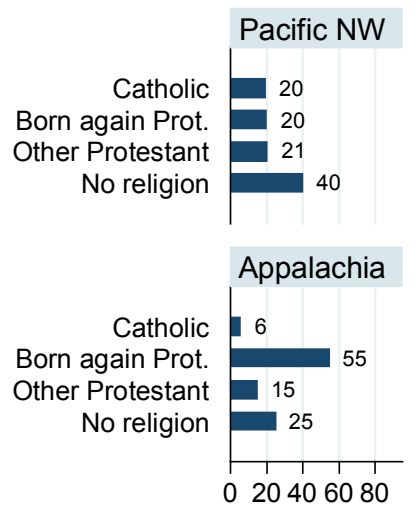

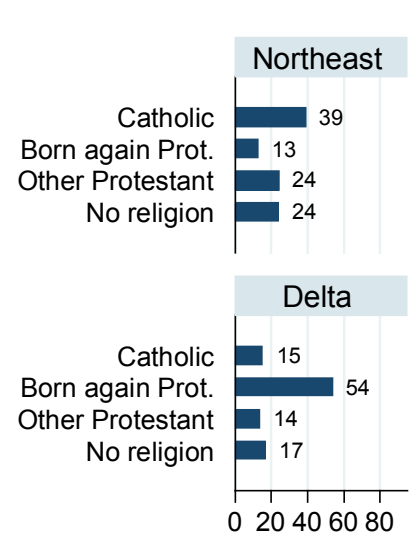

Given the importance of the evangelical vote in presidential and congressional elections, and the centrality of environmental issues in the current U.S. presidential campaign, could environmentalism be the new wedge issue among religious voters? If so, it will be important to learn more about one particular voting sector: the rural vote. Rural voters, who are more often evangelical, may see the effects of global warming first-hand, given the centrality of natural resources to their livelihoods. Rural voters are also often the swing vote in close elections. Yet many questions remain. What challenges do their views pose for church leaders and political candidates alike? Can we even talk about the rural vote when it comes to the environment, and if so, which political party might benefit from it?

This brief uses data gathered in 2007 from a representative survey of rural Americans selected from 9 clusters of 19 rural counties across the United States as part of the Carsey Institute's research on Community and Environment in Rural America (CERA). As documented in several other Carsey reports, rural America is not a homogeneous place, and our 7,842 survey respondents encompass this rural diversity. Some live in amenity-rich counties (13 percent) concentrated in the Rocky Mountain region. Some live in declining, resource-dependent communities (13 percent) in the Midwest. Others live in communities transitioning between amenity-rich and declining resource-dependent areas (35 percent), concentrated in the Northeast and the Northwest. Finally, a substantial number live in chronically poor communities (40 percent) in the Southeast. ${ }^{2}$ 


\section{Religious Affiliation and Practice in Rural America}

In general, rural Americans are far more likely to be Protestant (59 percent) than Catholic (16 percent), except in the Northeast (see Figure 1). And, as is true of the U.S. as a whole, ${ }^{3} 17$ percent are religiously unaffiliated. Similarly, a small but not insignificant minority of rural Americans (8 percent) report attachment to non-Christian religious and spiritual traditions. ${ }^{4}$

Among rural Protestants, nearly two-thirds (63 percent) are born-again Christians (that is, they have had a turning point in their lives when they personally committed to Jesus Christ). Born-again Protestants comprise 38 percent of the population in declining communities and 63 percent in chronically poor counties (see Figure 2). Rural residents with no religious affiliation are concentrated in amenity-rich communities, where they account for 41 percent of the population.

Similar to their urban and suburban peers, many rural Americans rarely attend church: 21 percent say that they never attend, and an additional 22 percent are only sporadic church-goers. ${ }^{5}$ At the other end of the spectrum, rural church-goers are more regular in their attendance than non-rurals. In our survey, 41 percent attend church at least once a week, and an additional 15 percent go to church once or twice a month. Church attendance is more frequent, almost double, in declining-resource and poor communities (where three-quarters of residents are Protestant), than in amenity-rich and amenitydeclining areas (see Figure 3).

Among rural Americans overall, Protestants (54 percent) are more likely than Catholics (44 percent) to report weekly church attendance. And rural Protestants, like their urban brethren, are characterized by a more elderly population; while 23 percent of rural Protestants are in the 65+ age group, this is true of 15 percent of rural Catholics. Not surprisingly then, more rural Protestants (24 percent) than Catholics (18 percent) are currently retired.

Both Catholics and Protestants are largely full-time, year-round residents (96 percent), and most have lived in their current community for at least 10 years (77 percent).
Figure 2. Religious Preference by Community Type

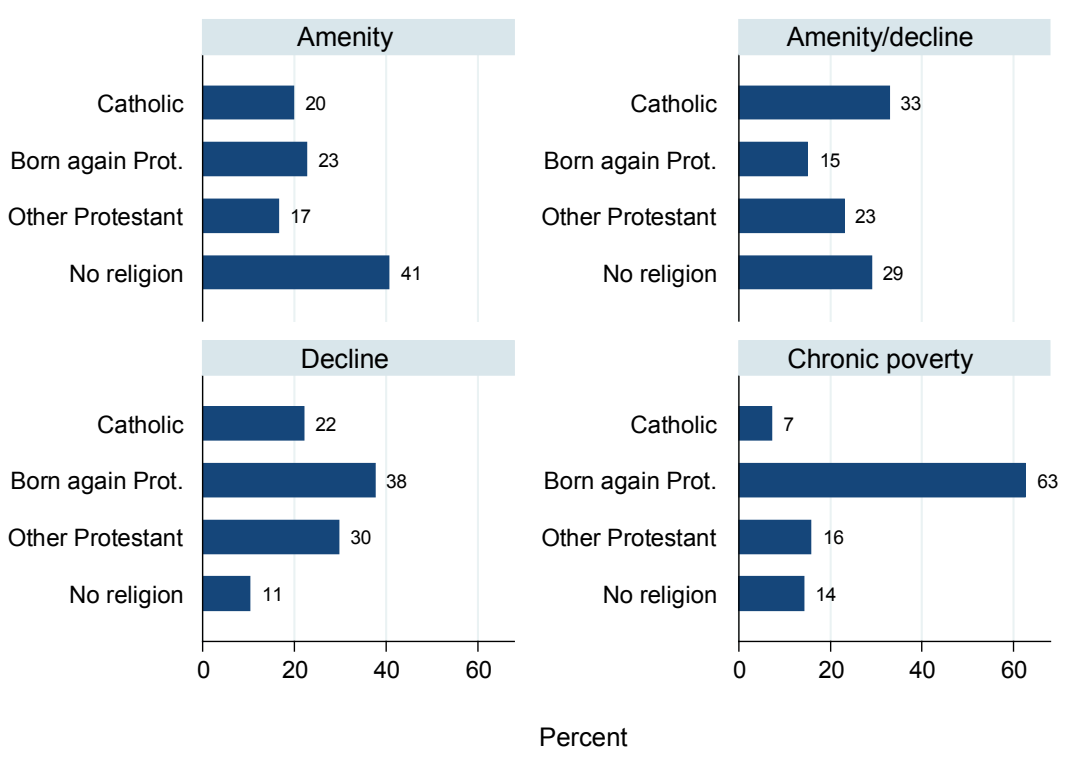

Figure 3. Church Attendance by Community Type

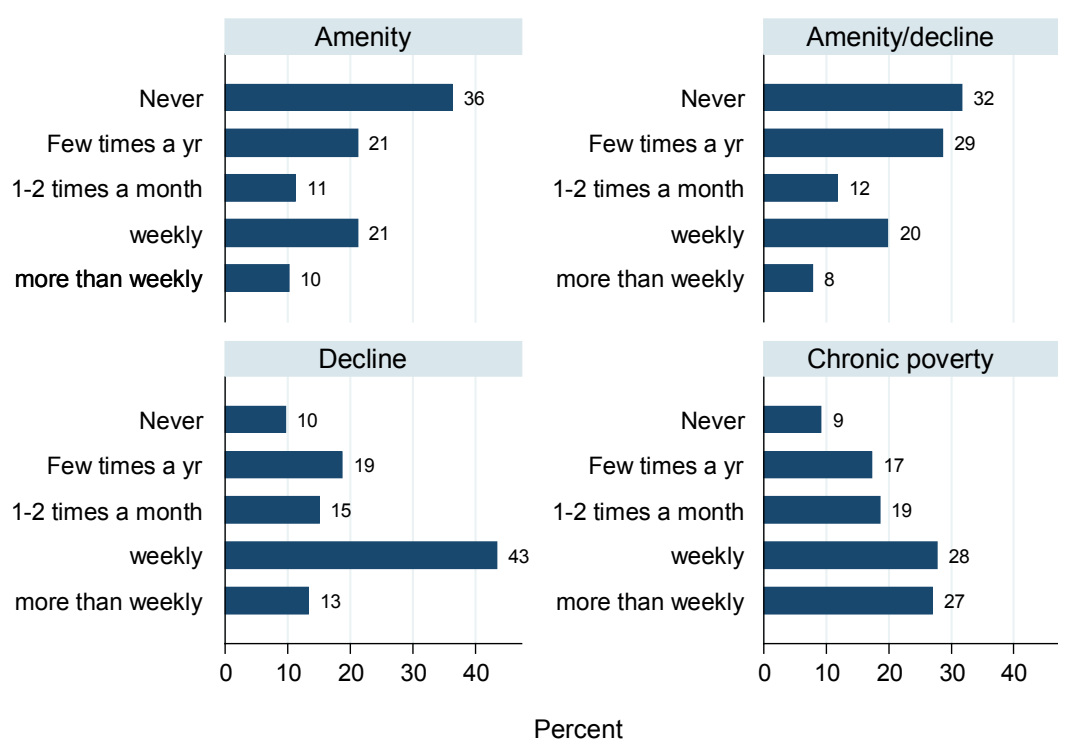




\section{Figure 4. Percentage Who Trust Neighbors, by Religion}

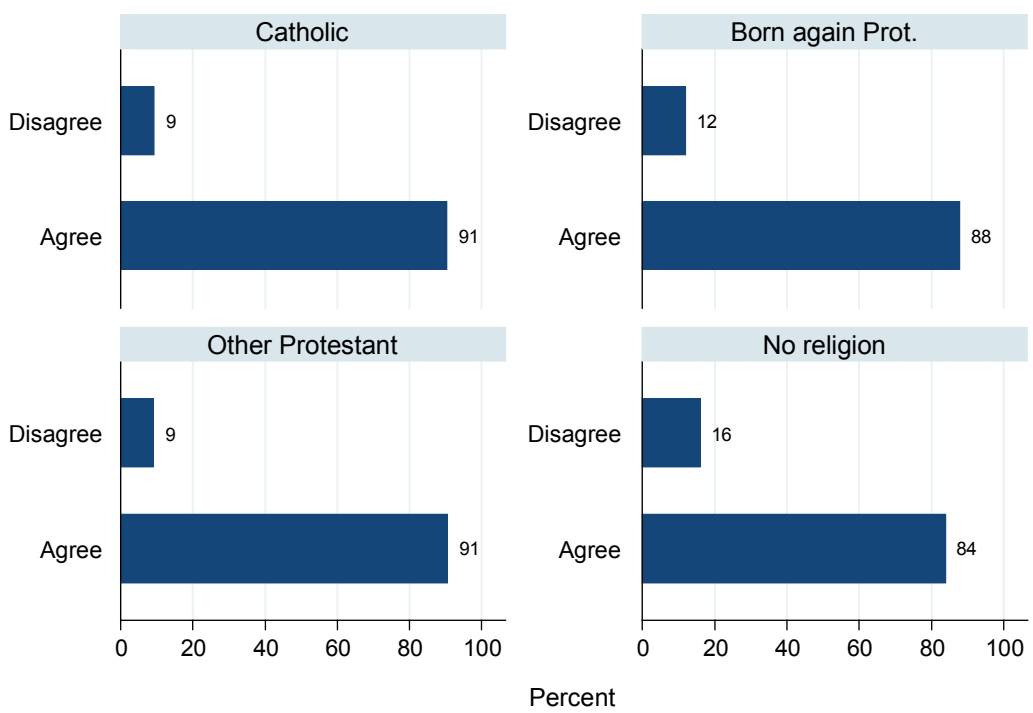

Note: Figure 4 shows the percentage agreeing with the statement "People in this community generally trust one another and get along."

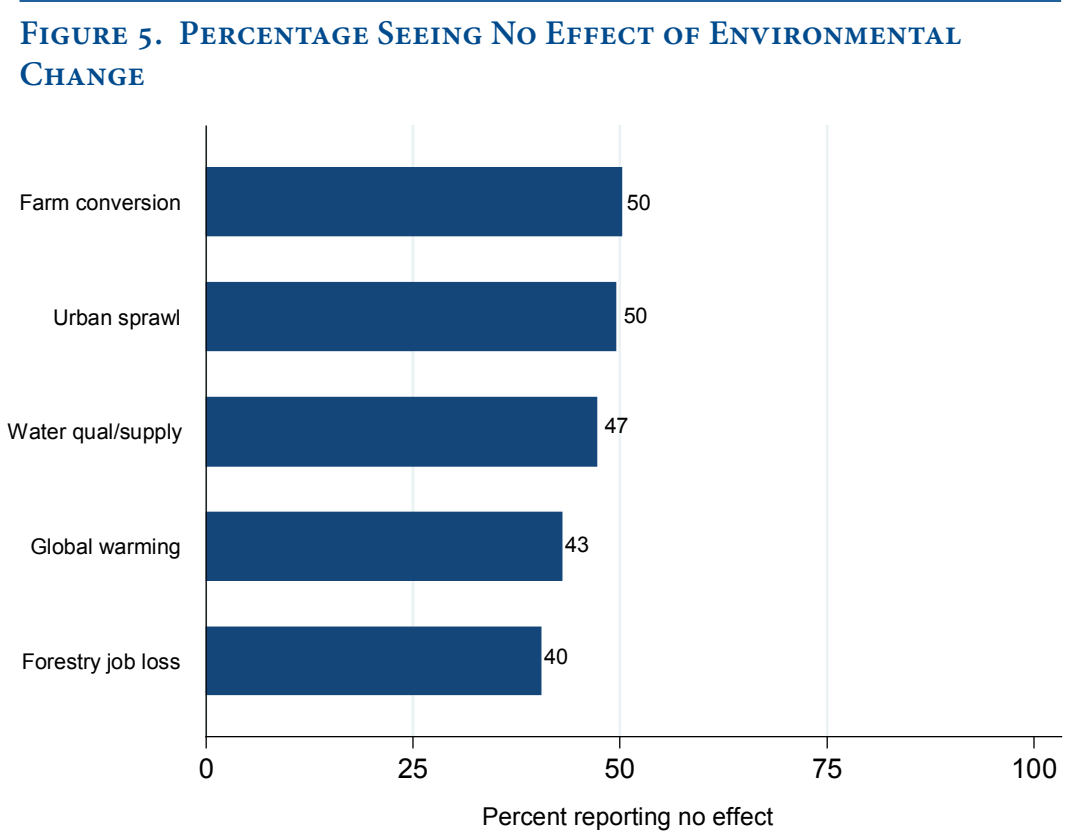

\section{Neighborliness}

Irrespective of differences in religious affiliation and practice, rural Americans have many shared experiences and attitudes. It is noteworthy, for example, that Catholics and Protestants, born-again and those who are not, and frequent church-goers as much as the unchurched, tend to express generally similar perceptions of neighborliness. Large majorities across these groups-close to 9 out of 10-agree that the community would bind together to work on some local problem, that people in the community are willing to help their neighbors, and that people in the community trust and get along with one another. Nonetheless, despite this overall pattern of shared perceptions of neighborliness, the religiously unaffiliated are slightly less likely than the affiliated to express neighborly trust (see Figure 4). Church is clearly an important locus of community networking and trust. This is useful to keep in mind as we consider the role of the church as a means of political mobilization.

\section{Environmental Conservation}

It is apparent from the survey that rural Americans are quite divided on environmental issues. When asked whether it is more important to use natural resources to create jobs or to conserve natural resources for future generations, 29 percent favor job creation, 43 percent say conservation should take priority, and 28 percent say that both priorities should be weighed equally. Slightly more than onethird of rural Americans (38 percent) believe that conservation or environmental rules that restrict development have been good for their community. Just 13 percent said that such zoning regulations have had negative effects. Almost half (46 percent) indicated that such rules have had no noticeable impact.

This division among rural Americans is also apparent in how they perceive the effects of various environmental issues in their respective communities. Five in ten say that the conversion of farmland to other uses, urban sprawl, and water quality have had no effects 
on their family or community in the past five years. Slightly fewer, however, think that climate change or global warming (43 percent) or the loss of forestry jobs (40 percent) has had no effects (see Figure 5).

\section{The Religious Divide in Environmental Attitudes}

Environmental attitudes in rural America vary by religious affiliation. Most notably, born-again Protestants are the least likely to express attitudes favoring environmental conservation. Specifically, only one-third compared with 40 percent of other Protestants, 41 percent of Catholics, and 43 percent of the unaffiliated say that rules restricting development are good (data not shown). And while born-again Protestants are more inclined to endorse resource conservation (40 percent), they are still less likely to do so than other rural Americans, particularly Catholics (49 percent) and the unaffiliated (48 percent) (see Figure 6). Born-again Protestants also stand out for their views on the effects of various environmental threats. In particular, they are significantly more likely than other rural Americans to say that urban sprawl and global warming have had no effects on their community (see Figure 7).

\section{The Born-Again Divide in Perceptions of Climate Change}

Quite apart from religion, variations in the natural and economic resources that characterize different communities affect residents' views of environmental issues. Individuals living in poor and declining communities (concentrated in Appalachia and the Midwest), are more likely than residents of amenity-rich and amenity-declining areas to perceive no effects of global warming and urban sprawl on their communities. ${ }^{6}$ When we look at how this general pattern is affected by religion, we see that within declining-resource based communities, born-again Protestants are significantly more likely than their non-born-again neighbors to say that global warming has had no effects in their community (see Figure 8). And further, born-again Protestants in declining communities are significantly
Figure 6. NAtural Resources Better Used for Jobs or Conservation, By Religion

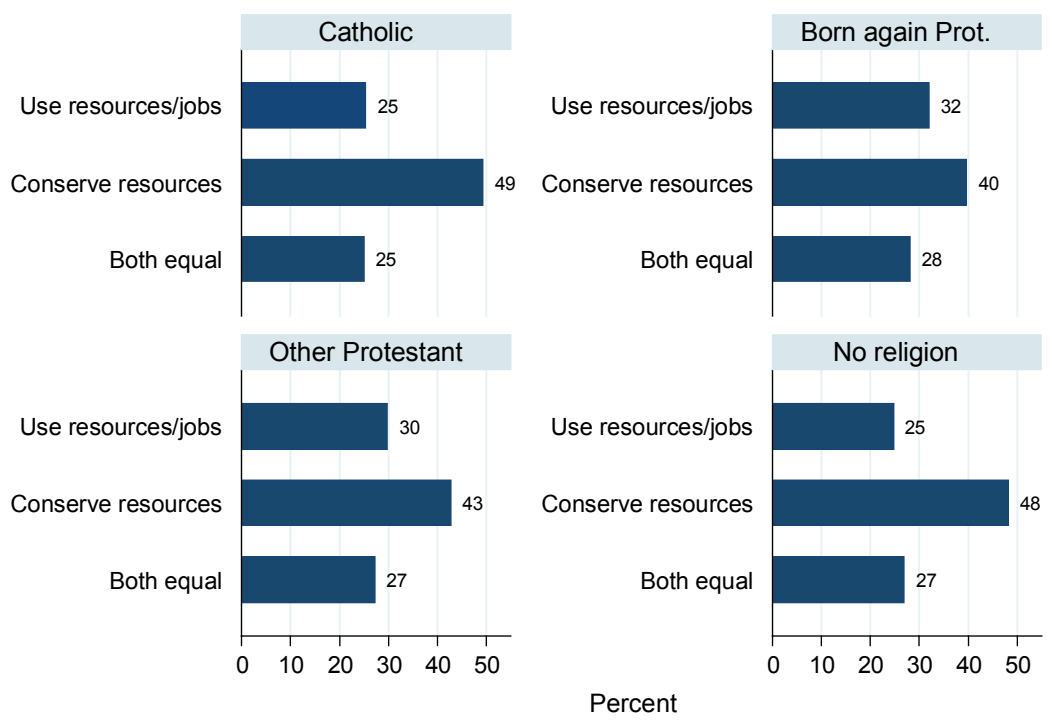

Figure 7. Percentage Reporting no Effect of Environmental Change, By Religion

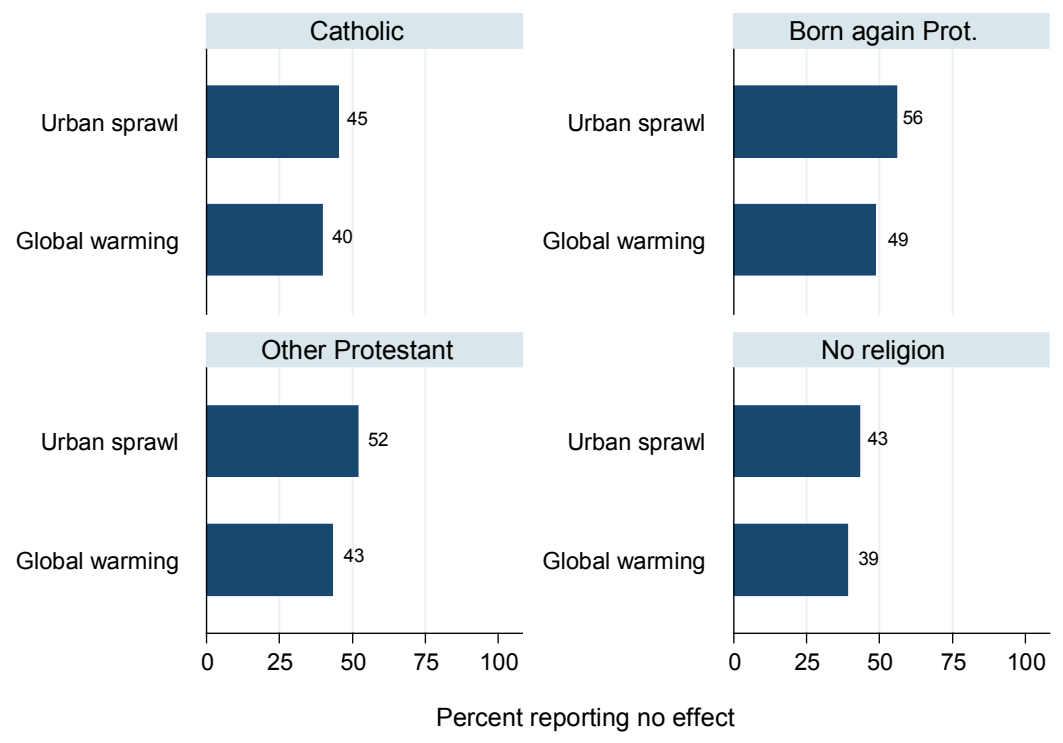


Figure 8. Percentage of Declining Area Residents Who See No Effect of Sprawl or Global Warming, by Evangelical Status

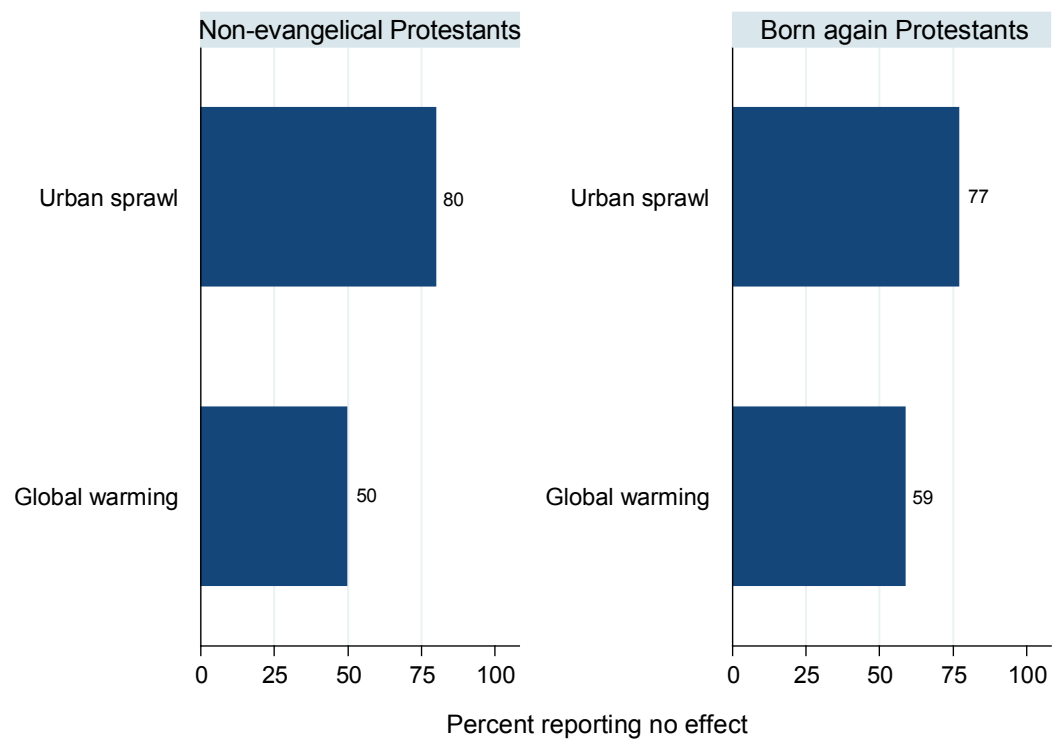

Figure 9. Percentage of Evangelicals Who See No Effect of Sprawl or Global Warming on Their Community, by Community TYPE

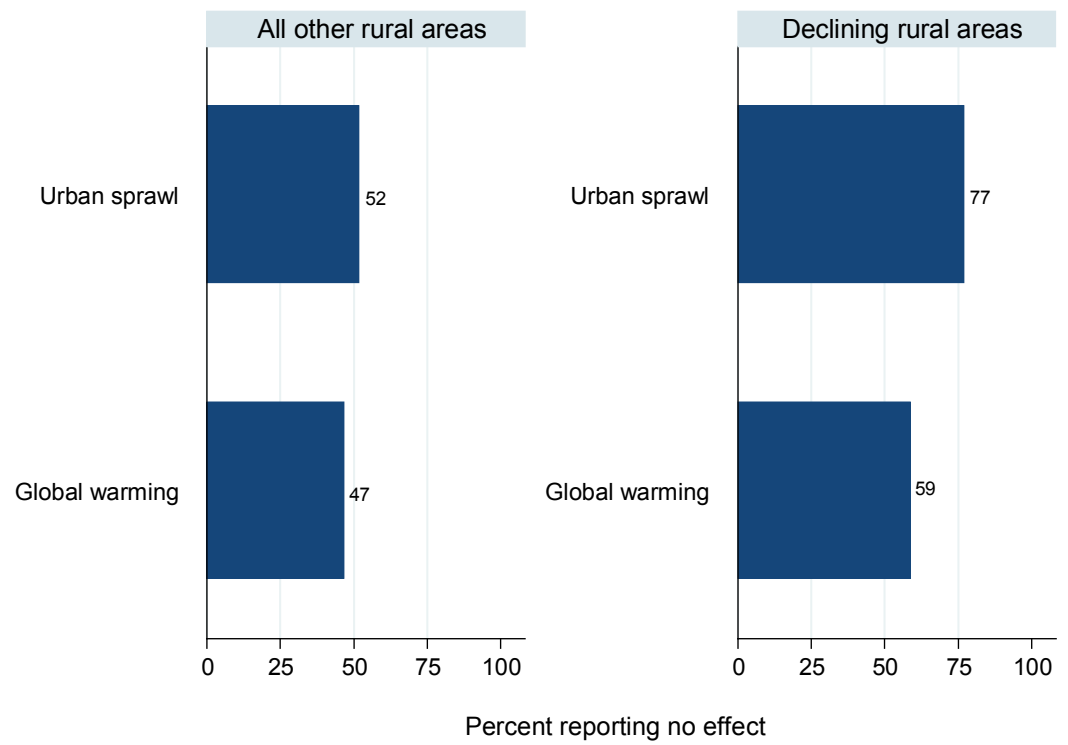

more likely than born-again residents in all other communities, including those in chronically poor counties, to say that global warming and urban sprawl have had no effects on their communities (see Figures 8 and 9). In short, it is a confluence of experiencing decline and being born again that seems to be particularly antithetical to the perception of environmental threat.

It is noteworthy that it is born-again Protestants in declining communities rather than in chronically poor communities, who are the least likely to perceive the effects of environmental change. We do not have longitudinal data that would enable us to unravel the causation involved here. On the one hand, it may be that while people living in persistently poor communities are resigned to their lot in life, those who live amidst economic decline may be inclined to respond in ways that scapegoat other social and cultural changes. Just as the issue of homosexual rights, for example, became a rallying cause for rural Oregonians facing the decline of the timber industry, ${ }^{7}$ the increased attention in the media and in corporate advertising today to the problems of global warming, may make anti-environmentalism a readily accessible way for religiously conservative rural Americans in declining communities to resist the economic changes around them. They may perceive environmental initiatives as the source of, rather than a response to, the economic decline in their communities. On the other hand, it may also be the case that disenchanted rural Americans in declining communities turn to bornagain Christianity as a way to cope with their community's economic decline; being born-again may provide an anchor amidst dwindling community resources. 


\section{Political Implications of Environmental Attitudes}

Rural America appears less attuned to the "going green" movement that currently pervades so much of American society, from the corporate boardroom to public housing and university sustainability initiatives. Approximately one-half of the rural Americans surveyed express no sense of urgency about environmental decline. If individuals, by and large, do not perceive the negative effects of environmental change in their own local communities, it is more difficult for them to rally around pro-environmental causes. Government and other initiatives to stem global warming, therefore, may find few politically mobilized allies in rural America.

It is also evident that the evangelical turn toward environmental activism does not necessarily translate into the lives of rural Protestants, the dominant rural population group. Rural Protestants, the majority of whom are born-again Christians, more accurately reflect the divide within the U.S. evangelical leadership on environmental issues. Whatever theological reasons may account for this evangelical division, our research points to the significance of variation in community natural resource and socioeconomic characteristics in shaping intra-religious divides.

Born-again Protestants in general are a strong constituency of the Republican Party. Among rural Americans, 41 percent of bornagain Protestants identify as Republican. This compares with much smaller proportions of other Protestants (35 percent), rural Catholics (27 percent), and the religiously unaffiliated (18 percent). The Democratic Party, however, does not benefit from these groups' allegiance. Rural Catholics and those with no religion are more likely to identify as Independent than Democratic (see Figure 10).
Figure 10. Political Affiliation by Religion

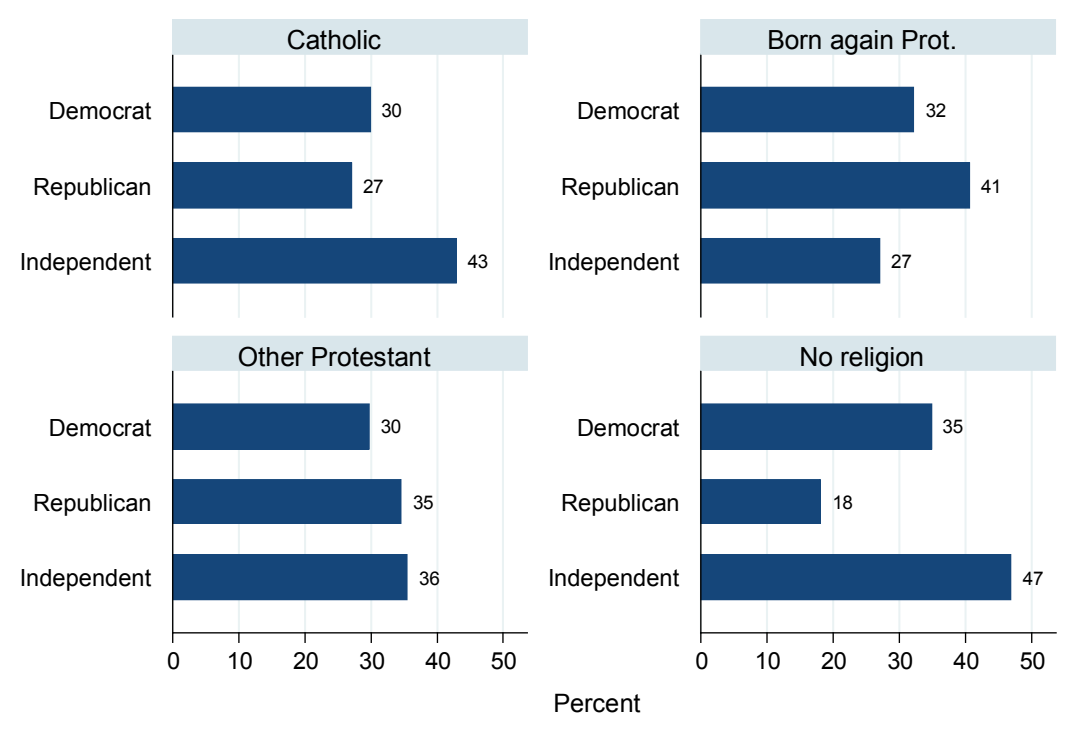


Given the crossover between religious and political affiliation in rural America, the Republican Party will likely benefit from heeding the environmental views of bornagain Protestants before embracing more environmentally friendly policies. Yet, as this report highlights, born-again Protestants are not of one mind when it comes to the environment. Some, particularly those living in amenityrich communities, are more likely than others to perceive the effects of global warming and other environmental changes. It is unlikely, therefore, that environmental policy can become a significant wedge issue pitting religious voters, and specifically born-again Christians, against others in the same way that abortion or same-sex marriage does. In addition, as on several other issues, the Republicans and the Democrats also have to keep an eye on securing the support of the many Independent rural Americans who express views that lean more toward environmental conservation. Further, most voters are not single-issue voters. Rural Americans in particular care about abortion and same-sex marriage ${ }^{8}$ undoubtedly, in any election, a candidate's stance on these issues will also figure into rural Americans' voting decisions.

\section{Endnotes}

1 Michelle Vu, "Evangelical leaders split over leader's global warming efforts," Christian Post (March 9, 2007), http:// www.christianpost.com/article/20070309/evangelicalboard-split-over-leader-s-global-warming-efforts.htm.

2 Distribution of rural areas described here reflects the survey's sample, which over-represents chronically poor communities. For further discussion of these areas, see Lawrence Hamilton, Leslie Hamilton, Mil Duncan, and Chris Colocousis, Place Matters: Challenges and Opportunities in Four Rural Americas. Reports on Rural America 1: 4 (Durham: University of New Hampshire, Carsey Institute, 2008).

3 Pew Forum on Religion and Public Life. 2008. U.S. Religious Landscape Survey. (Washington, D.C.: Pew Research Center).

4 Because we are interested in understanding the role of evangelicals, subsequent analysis omits non-Christians $(n=831)$ and those for whom evangelical status was not reported $(n=1312)$.

5 Michele Dillon and Sarah Savage, Values and Religion in Rural America: Attitudes Toward Abortion and SameSex Relations. Issue Brief \# 1 (Durham: University of New Hampshire, Carsey Institute, 2006).

6 Hamilton et al., Place Matters, p. 21.

7 Arlene Stein, The Stranger Next Door: The Story of a Small Community's Battle over Sex, Faith, and Civil Rights (Boston: Beacon Press, 2001).

8 Dillon and Savage, Values and Religion. 


\section{A U T H O R S}

Michele Dillon is a senior fellow at the Carsey Institute and professor of sociology at the University of New Hampshire.

Megan Henly is a graduate student in sociology at the University of New Hampshire.

\section{CARSEY \\ I N STITUTE}

Building knowledge for families and communities

The Carsey Institute at the University of New Hampshire conducts independent, interdisciplinary research and communicates its findings to policy makers, practitioners and the general public.

The Carsey Institute Reports on Rural America are supported by the Annie E. Casey Foundation's initiative to strengthen rural families, the Ford Foundation, and by the W.K. Kellogg Foundation.

Huddleston Hall

73 Main Street

Durham, NH 03824

(603) 862-2821

www.carseyinstitute.unh.edu

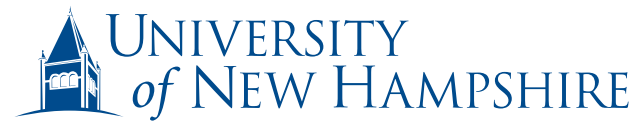

